\title{
Physiological and pathological functions of $\mathrm{P} 2 \mathrm{X} 7$ receptor in the spinal cord
}

\author{
Maria Luisa Cotrina $\cdot$ Maiken Nedergaard
}

Received: 29 April 2008 / Accepted: 15 July 2008 / Published online: 11 February 2009

(C) Springer Science + Business Media B.V. 2009

\begin{abstract}
ATP-mediated signaling has widespread actions in the nervous system from neurotransmission to regulation of proliferation. In addition, ATP is released during injury and associated to immune and inflammatory responses. Still, the potential of therapeutic intervention of purinergic signaling during pathological states is only now beginning to be explored because of the large number of purinergic receptors subtypes involved, the complex and often overlapping pharmacology and because ATP has effects on every major cell type present in the CNS. In this review, we will focus on a subclass of purinergic-ligand-gated ion channels, the P2X7 receptor, its pattern of expression and its function in the spinal cord where it is abundantly expressed. We will discuss the mechanisms for P2X7R actions and the potential that manipulating the P2X7R signaling pathway may have for therapeutic intervention in pathological events, specifically in the spinal cord.
\end{abstract}

Keywords ATP P Purinergic signaling $\cdot \mathrm{P} 2 \mathrm{X}$ receptors . Neuronal injury $\cdot \mathrm{P} 2 \mathrm{X} 7$ antagonists

\section{ATP as extracellular signaling pathway in the CNS}

Apart from its role as the main molecule that provides cellular fuel, ATP and other nucleotides function as intercellular signaling molecules when released to the extracellular space. Although considerable gaps exist in

M. L. Cotrina $(\triangle) \cdot$ M. Nedergaard

Division of Glial Disease and Therapeutics,

Center for Translational Neuromedicine,

University of Rochester Medical Center,

601 Elmwood Avenue,

Rochester, NY 14642, USA

e-mail: Marisa_Cotrina@urmc.rochester.edu our understanding of the pathways of intercellular purinergic signaling, it is clear that purinergic signaling represents the primary non-synaptic signaling mechanism in the normal and diseased CNS.

Purinergic receptors fall into two different categories: $\mathrm{P} 2 \mathrm{X}$ receptors-ligand-gated ion channels that allow nonspecific passage of cations $\left(\mathrm{Na}^{+}, \mathrm{Ca}^{2+}, \mathrm{K}^{+}\right)$-and $\mathrm{P} 2 \mathrm{Y}$ receptors-G-protein-coupled receptors that mediate intracellular calcium increases upon ATP binding [1]. So far, seven P2X receptors and eight P2Y receptors (as opposed to $\mathrm{P} 1$ receptors, which bind the nucleoside adenosine) have been described on the basis of their molecular structure and pharmacological profile (Table 1).

ATP signaling in brain affects not only neurons, but every other major cell types present in brain: astrocytes, microglia, oligodendrocytes, endothelial cells, and pericytes [2]. ATP-mediated signaling is widespread in the nervous system, mediating fast excitatory neurotransmission both in peripheral and central neurons (for review see [3]). ATP has also been considered to be a neuromodulatory substance because it is co-released with other neurotransmitters such as noradrenaline and GABA [4, 5]. In addition, ATP is the predominant (if not the sole) extracellular messenger that mediates calcium waves in astrocytic glial cells [6, 7], which are themselves involved in modulating neuronal activity [8-10]. ATP not only acts as a neurotransmitter, but it also stimulates cell proliferation and differentiation [11, 12]. Furthermore, while ATP-mediated activation of P2X receptors is linked to opening of a cation channel, and thereby either directly or indirectly to the increase of synaptic transmission, its related metabolite adenosine is a potent inhibitor of excitatory transmission via A1 receptor activation.

Importantly, ATP is ubiquitously present in the extracellular space after injury [13, 14]. It is therefore of 
Table 1 P2X receptors

\begin{tabular}{|c|c|c|c|c|}
\hline & $\begin{array}{l}\text { Affinity ATP } \\
\text { (EC50) }\end{array}$ & Agonists & Antagonists & $\begin{array}{l}\text { Inhibition by } \\
\text { divalent cations } \mathrm{s}^{\mathrm{a}}\end{array}$ \\
\hline $\mathrm{P} 2 \mathrm{x} 1$ & $1 \mu \mathrm{M}$ & BzATP $>$ ATP $=2 \mathrm{MeSATP}>\alpha, \beta-$ meATP & $\begin{array}{l}\text { Suramin, NF023, PPADS, TNP-ATP } \\
\text { IsoPPADS, NF449, Phenol Red, PPNDS } \\
\text { oATP (reversible) }\end{array}$ & $\mathrm{H}+, \mathrm{Zn}^{2+} \downarrow$ \\
\hline $\mathrm{P} 2 \mathrm{x} 2$ & $10 \mu \mathrm{M}$ & $\mathrm{ATP}>\operatorname{ATP} \gamma \mathrm{S} \geq 2 \mathrm{MeSATP}>>>\alpha \beta$ meATP & $\begin{array}{l}\text { Suramin, NF023, PPADS } \\
\text { RB-2, NF279 }\end{array}$ & $\begin{array}{l}\mathrm{Ca}^{2+} \downarrow \\
\mathrm{Zn}^{2+}, \mathrm{Cu}^{2+}, \mathrm{H}+\uparrow\end{array}$ \\
\hline $\mathrm{P} 2 \mathrm{x} 3$ & $1 \mu \mathrm{M}$ & $\mathrm{BzATP} \geq 2 \mathrm{meSATP} \geq \mathrm{ATP} \geq \alpha \beta$ meATP & $\begin{array}{l}\text { Suramin, NF023, PPADS, TNP-ATP } \\
\text { IsoPPADS, Phenol Red, A3174 }\end{array}$ & $\begin{array}{l}\mathrm{Ca}^{2+}, \mathrm{H}+\downarrow \\
\mathrm{Zn}^{2+} \uparrow\end{array}$ \\
\hline $\mathrm{P} 2 \mathrm{x} 4$ & $10 \mu \mathrm{M}$ & $\begin{array}{l}\text { ATP }>2 \text { meSATP }>\alpha, \beta \text {-meATP } \\
\text { Ivermectin (potentiates) }\end{array}$ & TNP-ATP (weak), BBG (weak) & $\begin{array}{l}\mathrm{H}+, \mathrm{Cu}^{2+} \downarrow \\
\mathrm{Zn}^{2+} \uparrow\end{array}$ \\
\hline $\mathrm{P} 2 \times 5$ & $10 \mu \mathrm{M}$ & $\mathrm{ATP}=2 \mathrm{MeSATP}=\mathrm{ATP} \gamma \gamma \mathrm{S}>\alpha \beta$ meATP & Suramin, PPADS, BBG & \\
\hline $\mathrm{P} 2 \mathrm{x} 6$ & $10 \mu \mathrm{M}$ & ATP $>2 \mathrm{MeSATP}>$ ADP & & \\
\hline $\mathrm{P} 2 \mathrm{x} 7$ & $>100 \mu \mathrm{M}$ & $\begin{array}{l}\text { BzATP }>>\text { ATP }>>\text { UTP }>>2 \text { meSATP } \\
>>\alpha \beta \text { meATP }\end{array}$ & 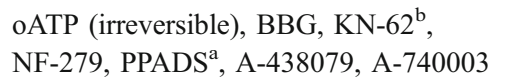 & $\mathrm{Ca}^{2+}, \mathrm{Mg}^{2+}, \mathrm{Cu}^{2+}, \mathrm{Zn}^{2+}, \mathrm{H}+\downarrow$ \\
\hline
\end{tabular}

Adapted from Bianchi et al. [107], North [15], Jacobson et al. [85], Burnstock [3]

${ }^{a}$ Effect of divalent cations on the current flow through the receptor ion channel. Downward-facing arrow Decreases, upward-facing arrow increases

${ }^{\mathrm{b}}$ Species differences (rat vs. human)

$B B G$ Brilliant blue G, BzATP 2'-and 3'-O-(4-benzoyl-benzoyl)-ATP, $\alpha, \beta$-meATP $\alpha, \beta^{\sim}$-methylene ATP, 2-MeSATP 2-metylthio ATP, ATP $\gamma S$ 5'-O(3-thiotriphosphate), $K N$-62 1-[N,O-bis(5-isoquinolinesulfonyl)- $N$-methyl-L-tyrosyl]-4-phenylpiperazine, $N F 023$ 8,8'-(carbonylbis(imino-3,1phenylenecarbonylimino))-bis(naphthalene-1,3,5-trisulfonic acid)-hexasodium salt, NF449 4,4',4",4"'-(carbonylbis(imino-5,1,3-benzenetriylbis (carbonylimino)))tetrakis-benzene-1,3-disulfonic acidoctasodium salt, PPADS pyridoxal-phosphate-6-azophenyl-2',4'-disulfonic acid, RB2 reactive blue, $o A T P$ periodate-oxidized ATP, TNP-ATP trinitrophenyl-substituted ATP

considerable interest to decipher the specific actions of ATP in pathological states and to explore the possibility that manipulating ATP-mediated signaling might help to diminish neuronal damage during disease.

\section{The $\mathbf{P} 2 \mathrm{X} 7$ receptor}

The $\mathrm{P} 2 \times 7 \mathrm{R}$ is significant because it is activated by high concentrations of ATP $(>100 \mu \mathrm{M})$ and because prolonged exposure to ATP is believed to form a much larger pore than any other P2X channel [15]. Thus, upon agonist application that lasts for several seconds, the $\mathrm{P} 2 \mathrm{x} 7$ receptor becomes permeable to larger ions, like the large cation $\mathrm{N}$ methy-D-glucamine (NMDG). The idea that ATP could induce the formation of a pore that allows the passage of large molecules came initially from studies in mast cells and macrophages [16] and Surprenant et al. [17] later defined the $\mathrm{P} 2 \times 7$ receptor as the molecular basis for the formation of a non-selective pore that could lead to cell death upon repeated agonist applications. Thus, P2X7Rs have been traditionally associated with cells from the immune system mediating cytotoxic cell death (because of changes in transmembrane ion fluxes, swelling and vacuolation), and inflammatory responses (because of release of large molecules, including pro-inflammatory mediators like IL-1 and tumor necrosis factor) [18].
P2x7R pore formation has, in general, been linked to cytolytic cell death, the uptake of calcium and fluorescent dyes and the release of inflammatory molecules. Upon ATP application, measure of the pore formation comes usually by monitoring the uptake of ethidium and YoPro1 dyes, which become fluorescent upon nucleic acids binding [19] or the release of IL-1 $\beta$ [20]. Importantly, the formation of a releasing-pore does not necessarily imply the existence of a cytolytic pore. This is the case of the astrocytic P2X7R that can release excitatory neurotransmitters upon BzATP activation but does not exhibit any of the signs of necrotic and/or apoptotic cell death [21].

Despite the extensive amount of data in favor of pore formation, the relationship between the $\mathrm{P} 2 \mathrm{x} 7 \mathrm{R}$ pore and the capability to uptake and release different molecules is not as straightforward as one might think. Thus, a critical question that remains in the field is how different the channel is compared to the pore. Although originally believed that pore formation was the result of true, progressive dilation of the channel [15], there is now the hypothesis that subsequent recruitment of proteins through interactions with the $\mathrm{C}$-t domain are required. Support for the involvement of downstream signaling pathways in addition to channel opening comes from the fact that some P2X7R-expressing cells fail to exhibit any other quality of pore formation [22], that there are reagents that affect BzATP induced pore formation without altering P2X7- 
mediated calcium influx or IL-1 $\beta$ release [23], that there is requirement for second messengers like calcium and MAP kinases for the $\mathrm{P} 2 \mathrm{X} 7$ pore [24] and that there exists alternative entry pathways for different molecules like $\mathrm{NMDG}^{+}$and Yo-Pro-1 upon P2X7R activation [25].

Some of the suggested accessory molecules that could contribute to the pore formation are pannexin [26]. Pannexins are a family of proteins structurally related to the innexins, non-mammalian proteins that form gap junctions (intercellular channels) in invertebrates [27]. Pannexins have been shown to co-immunoprecipitate with P2X7Rs and inhibitory peptides against pannexin or siRNA can diminish initial dye uptake and Il-1 $\beta$ processing and release-mediated by $\mathrm{P} 2 \mathrm{X} 7 \mathrm{R}$ without affecting ionic currents and slow dye uptake $[28,29]$.

\section{$\mathrm{P} 2 \mathrm{x} 7$ receptor expression and function in the spinal cord}

Given how dissimilar the P2X7R seems to be from the rest of the other P2X receptor subtypes, we will next review our current knowledge of $\mathrm{P} 2 \mathrm{X} 7$ receptors expression and function in the spinal cord, and the potential for therapeutic intervention based on selective administration of P2X7R antagonists. For a more detailed analysis of P2X7R in the rest of the central nervous system, please refer to [30].

P2X7R has been reported widely in several regions of the nervous system with post- and presynaptic actions affecting synaptic currents or neurotransmitter release, respectively (Table 2 for review, see [3, 15, 31]), although the actual functional implications of its presence are still under investigation.

\section{$\mathrm{P} 2 \mathrm{x} 7 \mathrm{R}$ in spinal cord neurons}

There has been ample debate about whether P2X7R is actually expressed in neurons because original data did not identify mRNA there [32]. However, Deuchars et al. [33] detected P2X7R mRNA in dorsal neurons and ventral motoneurons of the spinal cord using RT-PCR and in situ hybridization in slices. Other groups have later reported detectable mRNA and protein levels in neurons of several regions, including spinal cord (Table 2). At the level of protein expression, there is clear immunodetection in medulla, hippocampus, cerebellum, and cortex [33-35]. In the spinal cord, P2X7R immunoreactivity has been found associated to presynaptic neurons [33, 36, 37]. A strong immunoreactivity is also detected in motoneurons and terminals of the ventral spinal cord as opposed to cortical neurons that exhibit a much weaker signal [14]. Electrophysiological recordings from these neurons indicate the possible presence of post-synaptic terminals although additional studies combining pre- and post-synaptic markers are needed to clearly establish the exact location of the P2X7R in the ventral spinal cord.

The real identity of this anti-P2X7R reaction is still puzzling, given the controversial specificity of some of the antibodies used to recognize the P2X7R protein, although attempts have been made to confirm the identity of this P2X7R-like protein, like retrograde labeling or pharmacological and electrophysiological responses to agonists [14, 33]. Despite the fact that the antibodies available to date are able to recognize a Western band and protein corresponding to the P2X7 receptor in the submandibular gland, they are also capable of recognizing a P2X7R-like protein in neurons and astrocytes of the nervous system that is not eliminated in the $\mathrm{P} 2 \mathrm{X} 7-/-$ mice $[38,39]$.

Still, it is very possible that this protein corresponds to a differentially spliced protein or to a protein highly related to the $\mathrm{p} 2 \times 7 \mathrm{R}$ originally described in macrophages. This conclusion is supported by the pharmacological profile obtained in vivo, the ability to obtain permeability to large molecules upon activation and the blockage by the commonly used antagonists of the P2X7R [14, 33].

In an attempt to further clarify the issue, Yu et al. [40] have recently performed in situ hybridization using $\mathrm{S}^{35}$ labeled probes combined with immunohistochemistry with markers that differentiate between neuronal and glial populations. In this case, widespread labeling was detected in neuronal populations including cortex, hippocampus, and spinal cord, in ependymal cells and in glial cells of the adult rat nervous system.

In the spinal cord, physiological ATP actions affect fast synaptic currents [5], glycine release at dorsal horn interneural synapses [41], release of GABA and glutamate [42, 43] and glutamate-mediated excitation in dorsal horn cells [44-46] among others. P2X2, P2X2/3, P2X3, and other heteromeric receptors of not clear composition but involving, at least, $\mathrm{P} 2 \mathrm{X} 2, \mathrm{P} 2 \mathrm{X} 4$, and P2X6, have been described mostly associated to sensory pathways [43, 47]. In contrast, P2X7R has been unequivocally identified in relation to motoneurons pathways in the ventral spinal cord [14, 33, 40].

$\mathrm{P} 2 \mathrm{x} 7 \mathrm{R}$ in glial cells

In addition to neurons, P2X7R mRNA can also be detected in astrocytes [21] and microglial cells [32]. However, it is believed that the contribution of $\mathrm{P} 2 \mathrm{X} 7$ receptors to astrocytic physiology is negligible since astrocytic P2X7R protein levels have been more elusive to establish. On one hand, two groups have described P2X immunolabeling in hippocampal astrocytes using antibodies against the $\mathrm{p} 2 \mathrm{x} 7 \mathrm{R}$ subunits $[48,49]$. Pharmacological studies suggested that $\mathrm{p} 2 \times 7 \mathrm{R}$ could indeed be the receptor responsible for the ATP responses observed. Two studies [21, 50] later found pharmacological profiles of an astrocytic protein that 
Table 2 P2X7 in neurons and glia

\begin{tabular}{|c|c|c|c|c|}
\hline Cell type & Area & Method of detection & Function & References \\
\hline \multirow[t]{10}{*}{ Neurons } & Hippocampus & $\begin{array}{l}\text { mRNA, ICC, } \mathrm{Zn}^{2+}, \mathrm{BBG}, \\
\text { BzATP, RT-PCR }\end{array}$ & $\begin{array}{l}\text { Release of GABA, inhibition } \\
\text { of Glu currents, Presynaptic: } \\
\text { depression of synapses }\end{array}$ & $\begin{array}{l}{[34,35,37} \\
90,91]\end{array}$ \\
\hline & Cortex & $\begin{array}{l}\text { ICC, BzATP, BBG, OxATP, } \\
\text { Zn, PPADS, RT-PCR }\end{array}$ & & {$[37,90-92]$} \\
\hline & Cerebellum & ICC, BzATP, Zn, OxATP & Vesicular Glu release & {$[22,37,91,93]$} \\
\hline & Brainstem & ICC & & {$[37]$} \\
\hline & Hypothalamus & ICC & & {$[37]$} \\
\hline & Midbrain & ICC, BzATP, PPADS, KN-62 & presynaptic & [94] \\
\hline & DRG & mRNA, PCR & & {$[95]$} \\
\hline & Spinal cord $(\mathrm{VH}, \mathrm{DH})$ & $\begin{array}{l}\text { mRNA, ICC, BzATP, } \\
\text { PPADS, OxATP }\end{array}$ & Presynaptic excitatory,vesicular release & {$[14,33,36,37]$} \\
\hline & NMJ & ICC & Presynaptic excitatory,vesicular release & {$[33]$} \\
\hline & Retina & ICC, PCR & & {$[96,97]$} \\
\hline \multirow[t]{6}{*}{ Brain astrocytes } & Whole brain & $\begin{array}{l}\text { mRNA, PCR, BzATP, oATP, } \\
\text { BBG, ICC, Western }\end{array}$ & $\begin{array}{l}\text { Synthesis of leukotrienes, } \\
\text { regulation of AQP4 } \\
\text { Responds to MS lesion }\end{array}$ & {$[32,54,98-100$} \\
\hline & Hippocampus & ICC, BzATP, & $\begin{array}{l}\text { MAPK and chemokine activation, } \\
\text { release of Glu, Asp, LY pore }\end{array}$ & {$[21,48,49]$} \\
\hline & Cortex & PCR, Western, BzATP, oATP, BBG & EtBr pore, Akt phosphorylation & {$[50,101]$} \\
\hline & Fetal astrocytes (no) & PCR, Western, BzATP, KN-62 & NO release & {$[54]$} \\
\hline & IL1 activated astrocyte & & & \\
\hline & Hippocampus (no) & ICC, electrophysciology & & {$[52,53]$} \\
\hline \multirow[t]{2}{*}{ S.C. Astrocytes } & Spinal Cord & BBG, BzATP & ATP release for calcium waves, & {$[57]$} \\
\hline & Spinal Cord (no) & ICC & & {$[36]$} \\
\hline \multirow[t]{4}{*}{ Microglia } & Whole brain & $\begin{array}{l}\text { ICC, mRNA, BzATP, BBG, } \\
\text { electrophysiology, Western, } \\
\text { PCR, k/o }\end{array}$ & $\begin{array}{l}\text { Modulates microglial proliferation; } \\
\text { IL1 } \beta \text { secretion; TNF } \alpha \text { release, } \\
\text { Erk/p38 activation }\end{array}$ & $\begin{array}{l}{[32,61,70,} \\
76,102-104]\end{array}$ \\
\hline & Hippocampus & ATP, OxATP & Microglial apoptosis & {$[60],[62]$} \\
\hline & Cortex & ICC, RB2, BzATP, oATP, BBG & $\begin{array}{l}\text { Infarction response, superoxide and } \\
\text { NO release, neuronal death }\end{array}$ & {$[77,105]$} \\
\hline & Spinal cord & Western, ICC & & {$[63,73,75]$} \\
\hline Schwann cells & DRG & ICC, BzATP, oATP, mRNA & LY pore & {$[64,95]$} \\
\hline \multirow[t]{2}{*}{ Muller cells } & retina & ICC, PCR, BzATP, KN-62 & & {$[106]$} \\
\hline & Retina (no) & ICC & & {$[97]$} \\
\hline
\end{tabular}

$N M J$ Neuromuscular junction, $V H$ ventral horn, $D H$ dorsal horn, S.C. spinal cord, EtBr ethidium bromide, $L Y$ Lucifer Yellow, MS multiple sclerosis, $N O$ nitric oxide; (no) indicates no evidence of localization in this cell type

exhibited Lucifer Yellow or ethidium bromide permeability in response to BzATP or high ATP activation, respectively, consistent with presence of P2X7Rs. P2x7R has also been implicated in the regulation of calcium signaling by protein kinase $\mathrm{C}$ in an astrocytic cell line [51]. In contrast, an evaluation of the anti-P2X7R immunoreactivity observed in hippocampal sections of the $\mathrm{P} 2 \times 7 \mathrm{R}-1-$ mice has shown a subcellular localization incompatible with a plasmalemmal receptor in addition to absence of signal in astrocytes [52]. This same study also found that the responses obtained after addition of BzATP were indeed the result of the catabolic action of ectonucleotidases that degraded BzATP into BzAdenosine, triggering then actions trough the A1 receptors. Jabs et al. [53] have also failed to detect P2X7R currents in hippocampal astrocytic cultures.
It is not known whether these observations can be extended to astrocytes from another area. Similarly, not enough evidence exist to support the clear differences between astrocytes from brain vs. spinal cord since most of the reports on $\mathrm{P} 2 \mathrm{X} 7 \mathrm{R}$ in astrocytes come from culture preparations that could alter the expression profile. Still, there is inclination to believe that P2X7Rs are not predominant in astrocytes in general, which seem to rely more in $\mathrm{P} 2 \mathrm{Y}$ and other $\mathrm{P} 2 \mathrm{X}$ receptors to mediate purinergic signaling. Actually, a recent report examining the expression of P2X7R mRNA in the nervous system failed also to detect astrocytic signal for this receptor, as opposed to all the other major glial cell types [40].

However, despite low levels of P2X7R being confirmed also in human fetal brain astrocytic cultures, Narcisse et al. 
[54] have shown a significant transient increase in the levels of P2X7R mRNA and protein expression when these astrocytes were treated with the inflammatory molecule IL$1 \beta$, with concomitant YO-PRO1 permeability upon BzATP stimulation. Thus, it is possible that astrocytic purinergic signaling relies on different receptors depending on the conditions tested and that P2X7Rs in astrocytes become more prominent during pathological states.

P2X7R expressed in other glial cells could also contribute to the progression of neurodegeneration. This is particularly important when we think about putative loops of purinergic signaling between neurons and glia given the critical role astrocytes play in modulating neuronal excitability and synaptic function (reviewed in [55]). In the spinal cord, somatic ATP released by DRG neurons promotes P2X7R-mediated responses in the surrounding satellite cells that, by releasing $\mathrm{TNF} \alpha$, alter the $\mathrm{P} 2 \mathrm{X} 3 \mathrm{R}$ mediated responses and excitability of the DRG neurons [56]. The existence of positive and negative feedback between astrocytes and neurons in the spinal cord during injury and neurodegeneration could have tremendous impact in the progression and outcome of disease. In this regard, an enhanced P2X7R immunoreactivity is observed in astrocytes from autopsied tissue of multiple sclerosis patients [54]. Using spinal cord astrocytes from P2X7Rnull mice, Suadicani et al. [57] has recently found that, contrary to previous ideas, $\mathrm{P} 2 \mathrm{X} 7$ receptors could be responsible for intercellular calcium wave amplification when cells are exposed to solutions with low concentrations of divalent cations although the absence of P2X7R did not prevent the occurrence of astrocytic calcium waves. P2x7R activation and calcium signaling has also been described in optic nerve glia [58] and among bone cells [59]. These studies support the hypothesis that P2X7R could, indeed, directly mediate ATP release during episodes of astrocytic calcium signaling. In addition, Verderio and Matteoli [60] have shown that astrocytes can also transmit ATP-mediated calcium signals to co-cultured microglial cells via the $\mathrm{p} 2 \times 7 \mathrm{R}$ and that these effects were exacerbated by addition of interferon- $\gamma$, an inflammatory cytokine also released during injury.

In contrast to the conflicting reports on astrocytic expression, P2X7R can be unequivocally detected in microglia of cortex and spinal cord both at the mRNA and protein level [40,61-63] consistent with the abundance of this receptor in lymphocytes, monocytes, macrophages, and cells involved in immune responses. The functional implications of microglial P2x7R are enormous and will be discussed later in detail.

Optic nerve oligodendrocytes and DRG Schwann cells have also been described to express $\mathrm{P} 2 \mathrm{x} 7 \mathrm{R}$, based on current and calcium responses upon BzATP application, YO-PRO-1, or LY uptake in the presence of $1 \mathrm{mM}$ ATP and in situ RNA labeling that colocalizes with the oligodendrocytic marker OX-42 [40, 58, 64] although no particular function for $\mathrm{P} 2 \mathrm{x} 7 \mathrm{R}$ has yet been recognized in this cell type.

\section{Pathological role of $P 2 \times 7 R$ in spinal cord}

Purinergic signaling is often associated with pain and inflammatory responses. For instance, ATP is the major mediator of pain signaling in the spinal cord [19] and promotes the release of interleukin 1 and other proinflammatory cytokines during injury $[20,65]$.

Microglial P2x7R in neuropathic pain

$\mathrm{P} 2 \mathrm{X} 2$, P2X4, P2X6, P2X7, and P2X12 have been prominently described in microglia. Since ATP responses in microglia come mostly associated to injury, these receptors, specifically $\mathrm{P} 2 \mathrm{X} 4$ and $\mathrm{P} 2 \mathrm{X} 7$, have been linked to responses associated to spinal cord damage and inflammation being primary mediators of pain sensation. Thus, microglial $\mathrm{P} 2 \mathrm{X} 4 \mathrm{R}$ is responsible for the phenomenon of tactile allodynia, hypersensitivity to a non-painful stimulus after nerve damage [19]. P2X4R expression increases in microglia but not in neurons or astrocytes after spinal nerve injury. Knock-down studies revealed suppression of tactile allodynia after the injury [66]. A role for P2X7R in the development of neuropathic pain has come from studies where alteration in the P2X7 receptor pathway also shows reduction of neuropathic pain [65]. This receptor is also overexpressed in patients with chronic pain and disruption of the receptor leads to impairment in the production of IL-1 $\beta$, IL-10, and IL-6, evidencing its strong involvement in inflammatory responses [67, 65]. Importantly, systemic administration of P2X7R antagonists produced a dose-dependent reduction of neuropathic pain $[68,69]$. The exact mechanism by which ATP can produce neuropathic pain hypersensitivity might involve activation of the $\mathrm{p} 38 / \mathrm{ERK} / 2$ MAPK pathway $[70,66]$.

However, the uniqueness of the P2X7R as compared to other $\mathrm{P} 2$ receptors, with its ability to mediate formation of a large pore that allows directly or indirectly the passage of inflammatory molecules, the high ATP concentration required for its activation and its susceptibility to low calcium conditions, mostly attained under pathological conditions, has additionally pointed to this receptor as a major contributor during other diseased states. Consistent with this hypothesis an increase in P2X7R immunoreactivity has been observed in activated microglia of two transgenic models of Alzheimer's disease [71, 72] in microglia/ macrophages of spinal cord undergoing multiple or amyotrophic lateral sclerosis [73], in ischemic cortical tissue [74], and in a model of kainite-induced seizures [62] suggesting 
that microglial $\mathrm{P} 2 \mathrm{X} 7 \mathrm{R}$, together with $\mathrm{P} 2 \mathrm{X} 4 \mathrm{R}$, might be a general mediator of stress during pathological states. Besides uptake and release of inflammatory molecules, other pathways might contribute to microglial effects on neuronal excitability and disease outcome. For example, Morioka et al. [75] have recently shown that $\mathrm{p} 2 \times 7$ stimulation in spinal microglia produces downregulation of glutamate transport. Bianco et al. [76] have also reported the involvement of the P2X7R in modulation of the proliferation capability of microglia adding complexity to the mechanisms by which $\mathrm{P} 2 \mathrm{X} 7 \mathrm{R}$ can be involved in the microglial response to injury.

\section{Neuronal P2X7R in spinal cord injury}

Wang et al. [14] have analyzed the direct contribution of the $\mathrm{P} 2 \mathrm{X} 7$ receptors in the amplification of cell damage in a model of spinal cord injury. Using a bioluminescence technique in the intact, live animal, they found that the peritraumatic area after acute spinal cord injury exhibit unusually high levels of ATP release, which is accompanied by the subsequent cell death of spinal neurons highly immunoreactive for $\mathrm{P} 2 \mathrm{X} 7$ receptors. The same study showed that application of the P2X7R antagonist OxATP diminished spinal cord damage. Further studies in this model are needed to establish the source of ATP release during the injury period, but this work highlights the importance of the $\mathrm{P} 2 \mathrm{X} 7$ receptor and purinergic signaling as a potential target for therapeutic intervention in a number of traumatic and neurodegenerative disorders. Melani et al. [77] have also evaluated the effect of the P2 unselective antagonist Reactive Blue 2 in ischemia and found a reduction in the extent of ischemic brain damage. It is noteworthy to mention that Reactive Blue 2 promoted even more the expression of $\mathrm{P} 2 \mathrm{X} 7 \mathrm{R}$ in activated microglia.

Caution, however, must be exerted when applying purinergic antagonists for the treatment of diseased CNS conditions. oATP, an antagonist considered specific of P2X7Rs, affects pro-inflammatory responses independently from the activation of $\mathrm{P} 2 \mathrm{X} 7$ receptors because HUVEC, HEK293 and 1321N1 cells all secrete less IL-8 without expressing P2X7Rs [78]. P2X7R knock-out studies in autoimmune encephalomyelitis (EAE), an animal model of multiple sclerosis, have also shown a significant reduction in the protein levels of IL-1 and IL-6 with a concomitant decrease in lymphocytic apoptosis which, in turn, exacerbates the susceptibility to the disorder [79]. Similarly, a change in the pro-inflammatory profile by selective ablation of proliferating microglial cells exacerbates cell death and injury in the ischemic brain [80]. Thus, whereas interleukins levels are associated to inflammation, they are also important mediators in neuroprotection of the damaged tissues. Consistent with this idea is the fact that animals with $\mathrm{P} 2 \mathrm{X} 7 \mathrm{R}$ deletion show lack of protection against ischemic injury [81], although administration of exogeneous microglia and subsequent neuroprotection to global brain ischemia has also been reported [82].

In summary, ATP is released during injury and purinergic signalling can affect every major cell type in the diseased brain. ATP released from damaged neurons could stimulate ATP-dependent astrocytic calcium waves that, in turn, could affect neuronal, microglial and endothelial responses. Furthermore, ATP released from damaged neurons functions as chemotactile cue for microglia, which in turn can initiate inflammatory responses and phagocytosis [83]. Very promising therapeutic results have recently been obtained with compounds like the P2X7R antagonist oATP, which reduces neuronal cell death and improves functional recovery in a rat model of spinal cord injury [14], and the P2X4R modulator ivermectin, which promotes motoneuron survival in a model for amyotrophic lateral sclerosis [84].

\section{Future directions}

As the number of studies trying to elucidate the function of purinergic signaling increases, it has become more and more clear that this signaling mechanism is very complex. One reason why it has been difficult to fully understand the specific function of different ATP receptors relates to the pharmacological profile that has been described for them. The available drugs do not allow complete elucidation of the role of each receptor due to their actions on several P2 receptor subtypes. For example, BzATP is considered the most specific agonist for the $\mathrm{P} 2 \mathrm{X} 7$ receptors, but it has more potent actions on other $\mathrm{P} 2 \mathrm{X}$ receptors [85].

In addition, the available receptor antagonists are weak, may have different sensitivities depending on the species [85], or may have other pharmacological actions, like suramin, which can antagonize G-proteins [86]. In many cases, there are no specific antibodies that would enable us to establish the expression pattern of each receptor. For example, anti-P2X7R antibodies produce an immunoreactive signal that cannot be eliminated in mice deficient for this receptor [39].

Last, some of the receptors can form homo- or heteromultimers depending on the in vitro conditions used to study their pharmacology profile. This effect seems to vary in vivo and is cell-specific [87] The presence of different subunit composition involved in channel formation can, again, alter the pharmacology of the receptors and preclude us from knowing the true subtype involved in each cell type.

Yet another level of complexity in purinergic signaling comes from the fact that extracellular ATP has a short halflife once it is released. There are abundant ectonucleotidases in the cell surface that break down ATP into ADP, AMP, and adenosine, each of which can then act on different receptor 
subtypes. It is possible that ATP degradation products are responsible for some of the effects of ATP on synaptic plasticity and neuroprotection [88]. Studies on the pharmacological profile of $\mathrm{P} 2$ receptors may also be affected by the action of ectonucleotidases, as rapid degradation of the agonists can diminish their potency and result in a pharmacological profile that depends on agonist stability rather than the true binding affinity for the receptor [85]. In addition, the expression pattern of ectonucleotidases overlaps in vivo and it has not been easy to assign specific roles of these enzymes to each purinergic pathway [89].

Despite all these shortcomings and the debatable evidence about the specific localization of $\mathrm{p} 2 \times 7 \mathrm{R}$ in neurons and astrocytes of the spinal cord, it is clear that there exist ATP responses in the spinal cord mediated by P2X7-like receptors. The existence of oATP and other pharmacological compounds that can block these responses and thus diminish spinal cord damage have profound implications in the field of spinal cord regeneration. Whether these compounds are specific of a $\mathrm{p} 2 \times 7$ receptor per se or mediate their effects through a combination of mechanisms or through a highly related protein species should not diminish the importance of these findings. Rather, we should be encouraged by these results to further clarify the nature of the effects and refine the plethora of reagents that could be used for reducing spinal cord damage.

In addition, more studies to try to establish the true nature of purinergic signaling in the spinal cord and, by extension, the rest of the nervous system are guaranteed. Efforts should be directed into obtaining more specific antibodies for each receptor species, into improving the specificity of ATP receptors agonists and antagonists to unequivocally differentiate between receptors, into dissecting each of the cell types involved for each specific effect via cell-type-specific knock-outs taking into account the interplay between ATP and the related nucleotides, the role of nucleotidases and the striking presence of adenosine and adenosine receptors in spinal cord injury. Deciphering the exact molecular entities that result in a functional larger pore upon P2X7R activation, the existence of more downstream effectors and what the pore exactly does is also crucial in order to design meaningful therapeutic strategies to diminish receptor function during pathological states.

Acknowledgments This work was supported by NINDS NS38073, NS39559, and NS050315; The Adelson Program in Neural Repair and Regeneration, The New York State Spinal Cord Research Board, and the Robert Packard Center for ALS Research.

\section{References}

1. Burnstock G (2006) Purinergic signaling. Br J Pharmacol 147: S172-S181
2. Inoue K Koizumi S, Tsuda M (2007) The role of nucleotides in the neuron-glia communication responsible for the brain functions. J Neurochem 102:1447-1458

3. Burnstock G (2007) Physiology and pathophysiology of purinergic neurotransmission. Physiol Rev 87:659-797

4. Kennedy C, Saville VL, Burnstock G (1986) The contributions of noradrenaline and ATP to the responses of the rabbit central ear artery to sympathetic nerve stimulation depend on the parameters of stimulation. Eur J Pharmacol 122:21-300

5. Jo YH, Schlichter R (1999) Synaptic corelease of ATP and GABA in cultured spinal neurons. Nat Neurosci 2:241-245

6. Guthrie PB, Knappenberg J, Segal M, Bennett MV, Charles AC, Kater SB (1999) ATP from astrocytes mediates glial calcium waves. J Neurosci 19:520-528

7. Arcuino G, Lin JH, Takano T, Liu C, Jiang L, Gao Q, Kang J, Nedergaard M (2002) Intercellular calcium signaling mediated by point-source burst release of ATP. Proc Natl Acad Sci USA 99:9840-9845

8. Zhang J, Wang H, Ye C, Ge W, Chen Y, Jiang ZL, Wu CP, Poo MM, Duan S (2003) ATP released by astrocytes mediates glutamatergic activity-dependent heterosynaptic suppression. Neuron 40:971-982

9. Pascual O, Casper KB, Kubera C, Zhang J, Revilla-Sanchez R, Sul JY, Takano H, Moss SJ, McCarthy K, Haydon PG (2005) Astrocytic purinergic signaling coordinates synaptic networks. Science 310:113-116

10. Wang X, Lou N, Xu Q, Tian GF, Peng WG, Han X, Kang J, Takano T, Nedergaard M (2006) Astrocytic Ca2+ signaling evoked by sensory stimulation in vivo. Nat Neurosci 9:816-823

11. Agresti C, Meomartini ME, Amadio S, Ambrosini E, Serafini B, Franchini L, Volonté C, Aloisi F, Visentin S (2005) Metabotropic P2 receptor activation regulates oligodendrocyte progenitor migration and development. Glia 50:132-144

12. Franke H, Iles $P$ (2006) Involvement of $P 2$ receptors in the growth and survival of neurons in the CNS. Pharmacol Ther 109:297-324

13. Davalos D, Grutzendler J, Yang G, Kim JV, Zuo Y, Jung S, Littman DR, Dustin ML, Gan WB (2005) ATP mediates rapid microglial response to local brain injury in vivo. Nature Neurosci $8: 752-758$

14. Wang X, Arcuino G, Takano T, Lin J, Peng WG, Wan P, Li P, Xu Q, Liu QS, Goldman SA, Nedergaard M (2004) P2X7 receptor inhibition improves recovery after spinal cord injury. Nat Med 10:821-827

15. North A (2002) Molecular physiology of P2X receptors. Physiol Rev 82:1013-1067

16. Cockcroft S, Gomperts BD (1979) ATP induces nucleotide permeability in rat mast cells. Nature 279:541-542

17. Surprenant A, Rassendren F, Kawashima E, North RA, Buell G (1996) The cytolytic P2Z receptor for extracellular ATP identified as a P2X receptor (P2X7). Science 272:735-738

18. Le Feuvre R, Brough D, Rothwell N (2002) Extracellular ATP and $\mathrm{P} 2 \mathrm{X} 7$ receptors in neurodegeneration. Eur $\mathrm{J}$ Pharmacol 447:261-269

19. Khakh BS, North A (2006) P2X receptors as cell-surface ATP sensors in health and disease. Nature 442:527-532

20. Sanz JM, DiVirgilio F (2000) Kinetics and mechanism of ATPdependent IL-1 $\beta$ release from microglia cells. J Immunol 164:4893-4898

21. Duan S, Anderson CM, Keung EC, Chen Y, Chen Y, Swanson RA (2003) P2X7 receptor-mediated release of excitatory amino acids from astrocytes. J Neurosci 23:1320-1328

22. León D, Hervás C, Miras-Portugal MT (2006) P2Y1 and P2X7 receptors induce calcium/calmodulin-dependent protein kinase II phosphorylation in cerebellar granule neurons. Eur J Neurosci 23:2999-3013 
23. Donnelly-Roberts DL, Namovic M, Faltynek CR, Jarvis MF (2004) Mitogen-activated protein kinase and caspase signaling pathways are required for $\mathrm{P} 2 \mathrm{X} 7$ receptor (P2X7R)-induced pore formation in human THP-1 cells. J Pharmacol Exp Ther 308:1053-1061

24. Faria RX, DeFarias FP, Alves LA (2005) Are second messengers crucial for opening the pore associated with $\mathrm{P} 2 \mathrm{X} 7$ receptor? Am J Physiol Cell Physiol 288:C260-C271

25. Jiang LH, Rassendren F, Mackenzie A, Zhang YH, Surprenant A, North RA (2005) $N$-methyl-D-glucamine and propidium dyes utilize different permeation pathways at rat $\mathrm{P} 2 \mathrm{X} 7$ receptors. Am J Physiol Cell Physiol 289:1295-1302

26. Donnelly-Roberts DL, Jarvis MF (2007) Discovery of P2X7 receptor-selective antagonists offers new insights into $\mathrm{P} 2 \mathrm{X} 7$ receptor function and indicates a role in chronic pain states. Brit J Pharmacol 151:571-579

27. Hervé JC, Phelan P, Bruzzone R, White TW (2005) Connexins, innexins and pannexins: bridging the communication gap. Biochim Biophys Acta 1719:3-5

28. Pelegrin P, Surprenant A (2006) Pannexin-1 mediates large pore formation and interleukin- $1 \beta$ release by the ATP-gated P $2 \times 7$ receptor. EMBO J 25:5071-5082

29. Pelegrin P, Surprenant A (2007) Pannexin-1 couples to maitotoxin and nigericin-induced interleukin- $1 \beta$ release through a dye uptakeindependent pathway. J Biol Chem 4:2386-2394

30. Sperlách B, Vizi ES, Wirkner K, Illes P (2006) P2X7 receptors in the nervous system. Prog Neurobiol 78:327-346

31. Illes P, Ribeiro JA (2004) Molecular physiology of P2 receptors in the central nervous system. Eur J Pharmacol 483:5-17

32. Collo G, Neidhart S, Kawashima E, Kosco-Vilbois M, North RA, Buell G (1997) Tissue distribution of the P2X7 receptor. Neuropharmacol 36:1277-1283

33. Deuchars SA, Atkinson L, Booke RE, Musa H, Milligan CJ, Batten TF, Buckley NJ, Parson SH, Deuchars J (2001) Neuronal $\mathrm{P} 2 \mathrm{X} 7$ receptors are targeted to presynaptic terminals in the central and peripheral nervous system. J Neurosci 21:7143-7152

34. Sperlágh B, Köfalvi A, Deuchars J, Atkinson L, Milligan CJ, Buckley NJ, Vizi ES (2002) Involvement of P2X7 receptors in the regulation of neurotransmitter release in the rat hippocampus. J Neurochem 81:1196-211

35. Armstrong JN, Brust TB, Lewis RG, MacVivar BA (2002) Activation of presynaptic P2X7-like receptors depresses mossy fiber-CA3 synaptic transmission through p38 mitogen-activated protein kinase. J Neurosci 22:5938-5945

36. Deng Z, Fyffe RE (2004) Expression of P2X7 receptor immunoreactivity in distinct subsets of synaptic terminals in the ventral horn of rat lumbar spinal cord. Brain Res 1020:53-61

37. Atkinson L, Battern TF, Moores TS, Varoqui H, Erickson JD, Deuchars J (2004) Differential co-localization of the P2X7 receptor subunit with vesicular glutamate transporters VGLUT1 and VGLUT2 in rat CNS. Neurosci 123:761-768

38. Sim JA, Young MT, Sung HY, North A, Surprenant A (2004) Reanalysis of $\mathrm{P} 2 \mathrm{X} 7$ receptor expression in rodent brain. J Neurosci 24:6307-6314

39. Anderson CM, Nedergaard M (2006) Emerging challenges of assigning $\mathrm{P} 2 \mathrm{X} 7$ receptor function and immunoreactivity in neurons. TINS 29:258-262

40. Yu Y, Ugawa S, Ueda T, Ishida Y, Inoue K, Nyunt AK, Umemura A, Mase K, Yamada K, Shimada S (2008) Cellular localization of P2X7 receptor mRNA in the rat brain. Brain Res 1194:45-55

41. Rhee JS, Wang ZM, Nabekura J, Inoue K, Akaike N (2000) ATP facilitates spontaneous glycinergic IPSC frequency at dissociated rat dorsal horn interneuron synapses. J Physiol 524:471-483

42. Hugel S, Schlichter R (2000) Presynaptic P2X receptors facilitate inhibitory GABAergic transmission between cultured rat spinal cord dorsal horn neurons. J Neurosci 20:2121-2130
43. Nakatsuka T, Tsuzuki K, Ling JX, Sonobe H, Gu JG (2003) Distinct roles of $\mathrm{P} 2 \mathrm{X}$ receptors in modulating glutamate release at different primary sensory synapses in rat spinal cord. J Neurophysiol 89:3243-3252

44. Bardoni R, Goldstein PA, Lee CJ, Gu JG, MacDermott AB (1997) ATP P2X receptors mediate fast synaptic transmission in the dorsal horn of the rat spinal cord. J Neurosci 17:5297-5304

45. Gu JG, MacDermott AB (1997) Activation of ATP P2X receptors elicits glutamate release from sensory neuron synapses. Nature 389:749-753

46. Shiokawa H, Nakatsuka T, Furue H, Tsuda M, Katafuchi T, Inoue K, Yoshimura M (2006) Direct excitation of deep dorsal horn neurons in the rat spinal cord by the activation of postsynaptic P2X receptors. J Physiol 573:753-763

47. Nakatsuka T, Gu JG (2006) P2X purinoceptors and sensory transmission. Pflugers Arch 452:598-607

48. Panenka W, Jijon H, Herx LM, Armstrong JN, Feighan D, Wei T, Yong VW, Ransohoff RM, MacVivar BA (2001) P2X7-like receptor activation in astrocytes increases chemokine monocyte chemoattractant protein-1 expression via mitogen-activated protein kinase. J Neurosci 21:7135-7142

49. Kukley M, Barden JA, Steinhauser C, Jabs R (2001) Distribution of $\mathrm{P} 2 \mathrm{X}$ receptors on astrocytes in juvenile rat hippocampus. Glia $36: 11-21$

50. Fumagalli M, Brambilla R, D'Ambrosi N, Volonté C, Matteoli M, Verderio C, Abbracchio MP (2003) Nucleotide-mediated calcium signaling in rat cortical astrocytes. Role of P2X and P2Y receptors. Glia 43:218-230

51. Hung AC, Chu Y-J, Lin Y-H, Weng J-Y, Chen HB, Au Y-C, Sun SH (2005) Roles of protein kinase $\mathrm{C}$ in regulation of $\mathrm{P} 2 \mathrm{X} 7$ receptor-mediated calcium signaling of cultured type-2 astrocyte cell line, RBA-2. Cell Signal 17:1384-1396

52. Kukley M, Stausberg P, Adelmann G, Chessell IP, Dietrich D (2004) Ecto-nucleotidases and nucleoside transporters mediate activation of adenosine receptors on hippocampal mossy fibers by $\mathrm{P} 2 \mathrm{X} 7$ receptor agonist 2 '-3'-O-(4-benzoylbenzoyl)-ATP. J Neurosci 24:7128-7139

53. Jabs R, Grote A, Grauer M, Seifert G, Steinhauser C (2007) Lack of P2X Receptor mediated currents in astrocytes and GluR type glial cells of the hippocampal CA1 region. Glia 55:1648-1655

54. Narcisse L, Scemes E, Zhao Y, Lee SC, Brosnan CF (2005) The cytokine IL-1beta transiently enhances $\mathrm{P} 2 \mathrm{X} 7$ receptor expression and function in human astrocytes. Glia 49:245-258

55. Haydon PG, Carmignoto G (2006) Astrocyte control of synaptic transmission and neurovascular coupling. Physiol Rev 86:1009-1031

56. Zhang X, Chen Y, Wang C, Huang LYM (2007) Neuronal somatic ATP release triggers neuron-satellite glial cell communication in dorsal root ganglia. PNAS 104:9864-9869

57. Suadicani SO, Brosnan CF, Scemes E (2006) P2X7 receptors mediate ATP release and amplification of astrocytic intercellular $\mathrm{Ca}^{2+}$ signaling. J Neurosci 26:1378-1385

58. James G, Butt AM (2002) P2Y and P2X purinoceptor mediated $\mathrm{Ca} 2+$ signaling in glial cell pathology in the central nervous system. Eur J Pharmacol 447:247-260

59. Jorgensen NR, Henriksen Z, Sorensen OH, Eriksen EF, Civitelli R, Steinberg TH (2002) Intercellular calcium signaling occurs between human osteoblasts and osteoclasts and requires activation of osteoclast P2X7 receptors. J Biol Chem 277:7574-7580

60. Verderio C, Matteoli M (2001) ATP mediates calcium signaling between astrocytes and microglial cells: modulation by IFN- $\gamma$. J Immunol 166:6383-6391

61. Xiang Z, Burnstock G (2005) Expression of P2X receptors on rat microglial cells during early development. Glia 52:119-126

62. Rappold PM, Lynd-Balta E, Joseph SA (2006) P2X7 receptor immunoreactive profile confined to resting and activated microglia in the epileptic brain. Brain Res 1089:171-178 
63. Casanovas A, Hernández S, Tarabal O, Rosselló J, Esquerda JE (2008) Strong P2X4 purinergic receptor-like immunoreactivity is selectively associated with degenerating neurons in transgenic rodent models of amyotrophic lateral sclerosis. J Comp Neurol 506:75-92

64. Colomar A, Amédée T (2001) ATP stimulation of P2X7 receptor activates three different ionic conductances in cultured mouse Schwann cells. Eur J Neurosci 14:927-936

65. Chessell IP, Hatcher J, Bountra C, Michel AD, Hughes JP, Green P, Egerton J, Murfin M, Richardson J, Peck WL et al (2005) Disruption of the P2X7 purinoceptor gene abolishes chronic inflammatory and neuropathic pain. Pain 114:386-396

66. Inoue K (2006) ATP receptors of microglia involved in pain. Novartis Found Symp 276:263-272

67. Solle M, Labasi J, Perregaux DG, Stam E, Petrushova N, Koller BH, Griffiths RJ, Gabel CA (2001) Altered cytokine production in mice lacking P2X7 receptors. J Biol Chem 276:125-132

68. Honore P, Donnelly-Roberts D, Namovic MT, Hsieh G, Zhu CZ, Mikusa JP, Hernandez G, Zhong C, Gauvin DM, Chandran P, Harris R, Medrano AP, Carroll W, Marsh K, Sullivan JP, Faltynek CR, Jarvis MF (2006) A-740003 [N-(1-\{[(cyanoimino) (5-quinolinylamino) methyl] amino\}-2,2-dimethylpropyl)-2-(3,4dimethoxyphenyl) acetamide], a novel and selective P2X7 receptor antagonist, dose-dependently reduces neuropathic pain in the rat. J Pharmacol Exp Ther 319:1376-1385

69. Nelson DW, Gregg RJ, Kort ME, Perez-Medrano A, Voight EA, Wang Y, Grayson G, Namovic MT, Donnelly-Roberts DL, Niforatos W, Honore P, Jarvis MF, Faltynek CR, Carroll WA (2006) Structure-activity relationship studies on a series of novel, substituted 1-benzyl-5-phenyltetrazole P2X7 antagonists. J Med Chem 49:3659-3666

70. Suzuki T, Hide I, Katsutoshi I, Kohsaka S, Inoue K, Nakata Y (2004) Production and release of neuroprotective tumor necrosis factor by P2X7 receptor-activated microglia. J Neurosci 24:1-7

71. Parvathenani LK, Tertyshnikova S, Greco CR, Roberts SB, Robertson B, Posmantur R (2003) P2X7 mediates superoxide production in primary microglia and is up-regulated in a transgenic mouse model of Alzheimer's disease. J Biol Chem 278:12309-12317

72. McLarson JG, Ryuy JK, Walker DG, Choi HB (2006) Upregulated expression of purinergic $\mathrm{p} 2 \times 7$ receptor in Alzheimer disease and amyloid-beta peptide-treated microglia and in peptideinjected rat hippocampus. Neuropathol Exp Neurol 65:1090-1097

73. Yiangou Y, Facer P, Durrenberger P, Chessell IP, Naylor A, Bountra C, Banati RR, Anand P (2006) COX-2, CB2 and P2X7immunoreactivities are increased in activated microglial cells/ macrophages of multiple sclerosis and amyotrophic lateral sclerosis spinal cord. BMC Neurol 6:12

74. Franke H, Günther A, Grosche J, Schmidt R, Rossner S, Reinhardt R, Faber-Zuschratter H, Schneider D, Illes P (2004) $\mathrm{P} 2 \mathrm{X} 7$ receptor expression after ischemia in the cerebral cortex of rats. J Neuropathol Exp Neurol 63:686-699

75. Morioka N, Abdin MJ, Kitayama T, Morita K, Nakata Y, Dohi T (2008) P2X7 receptor stimulation in primary cultures of rat spinal microglia induces downregulating of the activity for glutamate transport. Glia 56:528-538

76. Bianco F, Ceruti S, Colombo A, Fumagalli M, Ferrari D, Pizzirani C, Matteoli M, Di Virgilio F, Abbracchio MP, Verderio C (2006) A role for P2X7 in microglial proliferation. J Neurochem 99:745-758

77. Melani A, Amadio S, Gianfriddo M, Vannucchi MG, Volonte C, Bernardi G, Pedata F, Sancesario G (2006) P2X7 receptor modulation on microglial cells and reduction of brain infarct caused by middle cerebral artery occlusion in rat. J Cereb Blood Flow Metab 26:974-982

78. Beigi RD, Kertesy SB, Aquilina G, Dubyak GR (2003) Oxidized ATP (oATP) attenuates proinflammatory signaling via P2 receptor-independent mechanisms. Br J Pharmacol 140:507-519
79. Chen L, Brosnan CF (2006) Exacerbation of experimental encephalomyelitis in $\mathrm{P} 2 \mathrm{X} 7 \mathrm{R}-1-$ mice: evidence for loss of apopototic activity in lympocytes. J Immunol 176:3115-3126

80. Lalancette-Hébert M, Gowing G, Simard A, Weng YC, Kriz J (2007) Selective ablation of proliferating microglial cells exacerbates ischemic injury in the brain. J Neurosci 27:25962605

81. Le Feuvre RA, Brough D, Touzani O, Rothwell NJ (2003) Role of $\mathrm{P} 2 \mathrm{X} 7$ receptors in ischemic and excitotoxic brain injury in vivo. J Cereb Blood Flow Metab 23:381-384

82. Imai F, Suzuki H, Oda J, Ninomiya T, Ono K, Sano H, Sawada M (2007) Neuroprotective effect of exogenous microglia in global brain ischemia. J Cereb Blood Flow Metab 27:488-500

83. Koizumi S, Shigemoto-Mogami Y, Nasu-Tada K, Shinozaki Y, Ohsawa K, Tsuda M, Joshi BV, Jacobson KA, Kohsaka S, Inoue $\mathrm{K}$ (2007) UDP acting at P2Y6 receptors is a mediator of microglial phagocytosis. Nature 446:1091-1095

84. Andries M, Damme PV, Robberecht W, Van Den Bosch L (2007) Ivermectin inhibits AMPA receptor-mediated excitotoxicity in cultured motor neurons and extends the life span of a transgenic mouse model of amyotrophic lateral sclerosis. Neurobiol Dis $25: 8-16$

85. Jacobson KA, Jarvis MF, Williams M (2002) Purine and pyrimidine (P2) receptors as drug targets. J Med Chem 45: 4057-4093

86. Freissmuth M, Boehm S, Beindl W, Nickel P, Ijzerman AP, Hohenegger M, Nanoff C (1996) Suramin analogues as subtypeselective G protein inhibitors. Mol Pharmacol 49:602-611

87. North RA, Surprenant A (2000) Pharmacology of cloned P2X receptors. Annu Rev Pharmacol Toxicol 40:563-580

88. Ciccarelli R, Ballerini P, Sabatino G, Rathbone MP, D’Onofrio M, Caciagli F, Iorio P (2001) Involvement of astrocytes in purine-mediated reparative processes in the brain. Int $\mathrm{J}$ Devl Neurosci 19:395-414

89. Zimmermann H (2006) Ectonucleotidases in the nervous system. Novartis Found Symp 276:113-128

90. Sperlágh B, Szabó G, Erdélyi F, Baranyi M, Vizi ES (2003) Homo- and heteroexchange of adenine nucleotides and nucleosides in rat hippocampal slices by the nucleoside transport system. Br J Pharmacol 139:623-633

91. Sánchez-Nogueiro J, Marín-García P, Miras-Portugal MT (2005) Characterization of a functional P2X7-like receptor in cerebellar granule neurons from P2X7 knockout mice. FEBS Lett 579:3783-3788

92. Lundy PM, Hamilton MG, Mi L, Gong W, Vair C, Sawyer TW, Frew R (2002) Stimulation of $\mathrm{Ca} 2+$ influx through ATP receptors on rat brain synaptosomes: identification of functional P2X7 receptor subtypes. Br J Pharmacol 135:1616-1626

93. Hervás C, Pérez-Sen R, Miras-Portugal MT (2005) Presence of diverse functional $\mathrm{P} 2 \mathrm{X}$ receptors in rat cerebellar synaptic terminals. Bioch Pharmacol 70:770-785

94. Miras-Portugal MT, Díaz-Hernández M, Giráldez L, Hervás C, Gómez-Villafuertes R, Sen RP, Gualix J, Pintor J (2003) P2X7 receptors in rat brain: presence in synaptic terminals and granule cells. Neurochem Res 28:1597-1605

95. Kobayashi K, Fukuoka T, Yamanaka H, Dai Y, Obata K, Tokunaga A, Noguchi K (2005) Differential expression patterns of mRNAs for P2X receptor subunits in neurochemically characterized dorsal root ganglion neurons in the rat. J Comp Neurol 481:377-390

96. Brändle U, Kohler K, Wheeler-Schilling TH (1998) Expression of the P2X7-receptor subunit in neurons of the rat retina. Mol Brain Res 62:106-109

97. Ishii K, Kaneda M, Li H, Rockland KS, Hashikawa T (2003) Neuron-specific distribution of P2X7 purinergic receptors in the monkey retina. J Comp Neurol 459:267-277 
98. Ballerini P, Ciccarelli R, Caciagli F, Rathbone MP, Werstiuk ES, Traversa U, Buccella S, Giuliani P, Jang S, Nargi E, Visini D, Santavenere C, Di Iorio P (2005) P2X7 receptor activation in rat brain cultured astrocytes increases the biosynthetic release of cysteinyl leukotrienes. Int J Immunopathol Pharmacol 18:417-430

99. D'Alimonte I, Ciccarelli R, Di Iorio P, Nargi E, Buccella S, Giuliani P, Rathbone MP, Jiang S, Caciagli F, Ballerini P (2007) Activation of $\mathrm{P} 2 \mathrm{X}(7)$ receptors stimulates the expression of $\mathrm{P} 2 \mathrm{Y}$ (2) receptor mRNA in astrocytes cultured from rat brain. Int $\mathrm{J}$ Immunopathol Pharmacol 20:301-316

100. Lee M, Lee SJ, Choi HJ, Jung YW, Frøkiæ J, Nielsen S, Kwon TH (2008) Regulation of AQP4 protein expression in rat brain astrocytes: role of $\mathrm{P} 2 \mathrm{X} 7$ receptor activation. Brain Res 1195:1-11

101. Jacques-Silva MC, Rodnight R, Lenz G, Liao Z, Kong Q, Tran M, Kang Y, Gonzalez FA, Weisman GA, Neary JT (2004) P2X7 receptors stimulate AKT phosphorylation in astrocytes. $\mathrm{Br} \mathrm{J}$ Pharmacol 141:1106-1117

102. Hide I, Tanaka M, Inoue A, Nakajima K, Kohsaka S, Inoue K, Nakata Y (2000) Extracellular ATP triggers tumor necrosis factor- $\alpha$ release from rat microglia. J Neurochem 75:965-972
103. Chafke Y, Seguin R, Antel JP, Morissette C, Malo D, Henderson D, Séguéla P (2002) ADP and AMP induce Interleukin-1b release from microglial cells through activation of ATP-primed P2X7 receptor channels. J Neurosci 22:3061-3069

104. Mingam R, De Smedt V, Amédée T, Bluthé RM, Kelley KW, Dantzer R, Layé S (2008) In vitro and in vivo evidence for a role of the P2X7 receptor in the release of IL-1 beta in the murine brain. Brain Behav Immun 22:234-44

105. Skaper SD, Facci L, Culbert AA, Evans NA, Chessell I, Davis JB, Richardson JC (2006) P2X7 receptors on microglial cells mediate injury to cortical neurons in vitro. Glia 54:234-242

106. Pannicke T, Fischer W, Biedermann B, Schädlich H, Grosche J, Faude F, Wiedemann P, Allgaier C, Illes P, Burnstock G, Reichenbach A (2000) P2X7 receptors in Müller glial cells from the human retina. J Neurosci 20:5965-5972

107. Bianchi BR, Lynch KJ, Touma E, Niforatos W, Burgard EC, Alexander KM, Park HS, Yu H, Metzger R, Kowaluk E, Jarvis MF, van Biesen T (1999) Pharmacological characterization of recombinant human and rat $\mathrm{P} 2 \mathrm{X}$ receptor subtypes. Eur J Pharmacol 376:127-138 